\title{
温熱環境とエネルギー消費量の同時評価法に関する研究
}

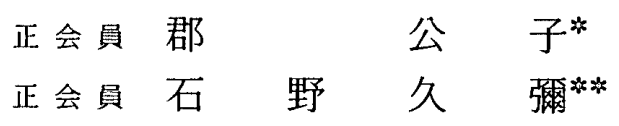

\section{1. 序文}

空調システムはその本来の使命として，まず第 1 に人 体にとって快適な室内環境を具現し，そのうえで，いか にエネルギー消費を抑えるかが問題となり得る。図一1 は空気調和を熱的構造の観点からまとめたものである。 人体側の要求により室内設定温湿度などが決められる が，実際には常に設定温湿度に保たれるわけではなく， 建物の熱特性，システムの制御特性に絡む制約を受けて 温湿度スウィングを起こすことがある。このとき，シス テム側の制約としては，冷温熱源それぞれ稼動期が定め られていること，ゾーニングが不十分であること，冷房 期は通常顕熱制御のみであること，制御能力の限界があ るなどが抽出できる。また，仮に室内温湿度が一定であっ たとしても，人体の快適性という点からは，ふく射環境

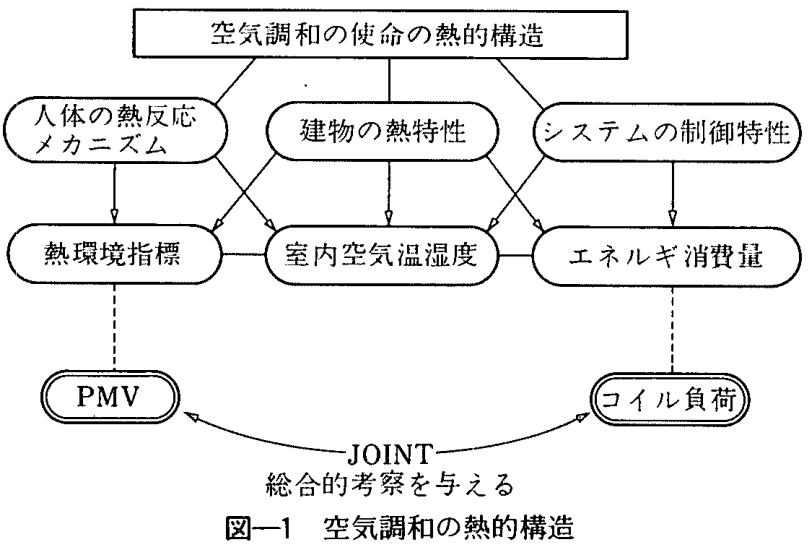

が無制御であるために温熱環境として適しているとは限 らない。このため,室温でなくできるだけ人間の温冷感・ 快適感に近い指標で温熱環境を表現することが重要であ る。そこで筆者らは従来, 事務所ビルを対象とし, 熱環 境指標としては, 計算が簡明であり熱的最適点も表現し 得る F anger の PMV をとりあげ，またエネルギー消費 量としては, 特に室内温熱環境制御性に深く関係する空 調機に重点を置き，コイル負荷を用いた。コイル負荷は， 従来よく用いられる室除去熱量に比較して,ゾーニング, 温湿度制御法，外気冷房など，空調を 1 つの系としてと らえたものでありエネルギー消費と密接なつながりをも つという点に長所を有する。そして図一1にも示したよ うに，PMVをコイル負荷を同一の場で評価，検討でき ることに最重点を置いた。計算法の特質としては，実務 的汎用性は要求しないので, 精度の向上を重視し計算時 間の短縮などの工夫は軽視した。

本論は，筆者らが今日まで検討してきた計算理論をま とめたものであり，文献1）で発表済のものをもとに， 空調システムの㹡張と最大負荷予熱計算が可能なように 改良したものである。空調機まわり，室まわり，温熱環 境に関する基本的な計算法について，顕熱処理量に対す る室温重み係数を用いた空調時室温計算法およびその最 大負荷計算への展開法について述べ, 主要部計算流れ図 も示した。本報告で提案する手法を実際に適用した計算 例については引き続き報告する予定である。

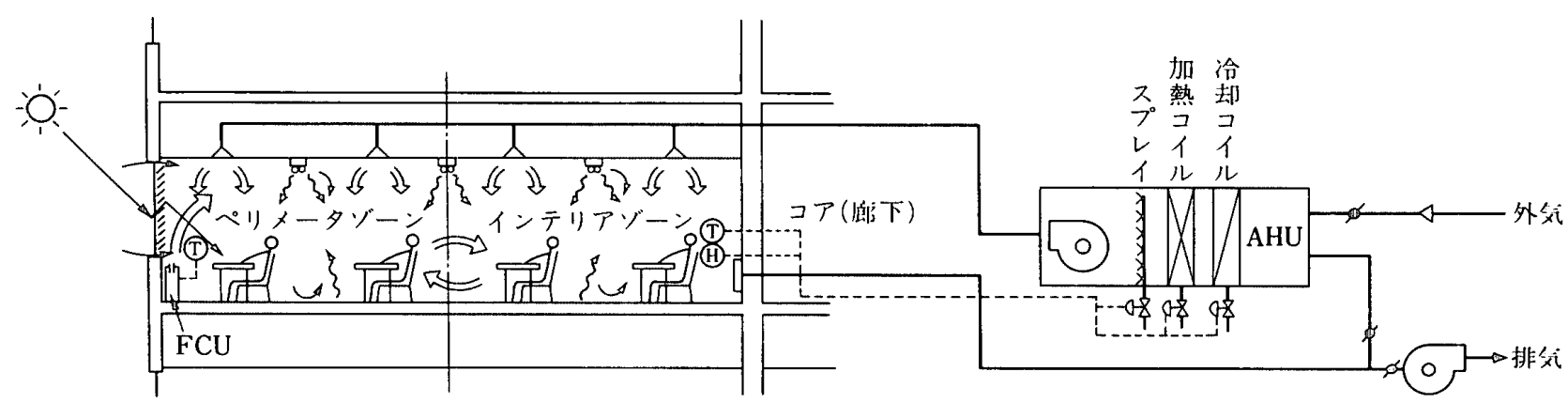

图一2 断面概観図（事務所ビル想定）

\footnotetext{
*宇都宮大学 助手.工修

東京都立大学 助教授.工博 (昭和 60 年 11 月 11 日原稿受理) 


\section{2. 各部の基本的計算法注1)}

2.1 モデル建物および主要計算部の構成

図一2に, 標準計算モデルとしての事務所ビル基準階 一方位の断面概観図を示す。空調方式は, 空調機 (AHU) によってインテリアとペリメータ両ゾーンに調和空気を 送風させて，空側にはファンコ イルユニット（FCU）を設置 している。AHUはインテリア のサーモスタット・ヒューミ ディスタットによって制御され るものとし, ペリメータの FCUはAHUで処理できな かったペリメー夕負荷を受け持 つこととする。

計算は空調機まわりの計算, 室まわりの計算, 温熱環境の計 算に大別される。空調機まわり の計算は, 室内温湿度, 要求さ れる熱処理量をもとに送風空気 状態, 実際の熱処理量を求め, 室まわりの計算は，システムで の熱処理量を既知として室内温 湿度,壁表面温度の計算を行う。 室内温湿度スウィングを起こす ときは，両者の計算を何度も繰 り返すこともある。そして得ら れた室内温湿度，壁表面温度よ り，各ゾーン数点について PMV が求まることになる。

\section{2 空調機まわりの計算}

AHU あるいはFCU での熱 交換プロセスを分類すると表一 1のようなパターンになる。表 -1 の空気線図上の変化は単一 ダクトの AHU の場合である が，FCU の場合は表中の記号 の $\mathrm{M}$ と R が一致することにな り，二重ダクトの場合は冷風， 温風別々に考えれば同様に適用 することができる。実際のある システムが表一1 のどのパター ンになるかは，その空調方式と そのときの理想とする要求送風 空気状態とによって定まるもの である。そこで図一3のような 各種温湿度制御方式における熱 交換プロセスパターンの識別方 法を表一2にまとめた。空調方 $\mathrm{S}^{\prime}$ : 实现送風空気 同棣である。

式，温湿度制御法，熱供給状態から表一 2 のどのブロッ クの判別式になるかをさがし，判別式によってプロセス パターンを決定する。どのプロセスパターンに属するか が判明すれば，パターンごとに実際の送風空気状態と交 換熱量を求めることができる。すなわち表一1の空気線

表一1 プロセスパターンでの機能と空気状態変化

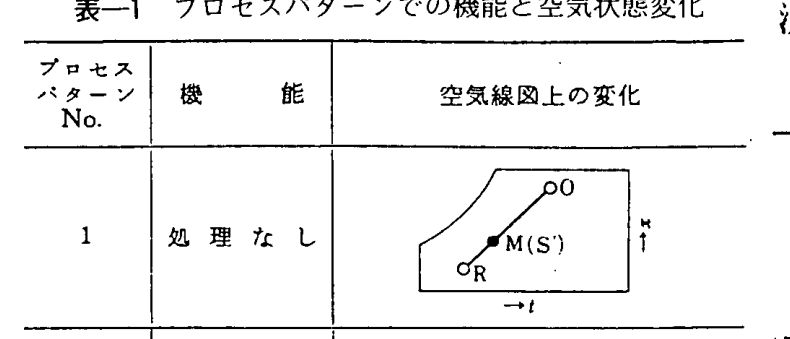
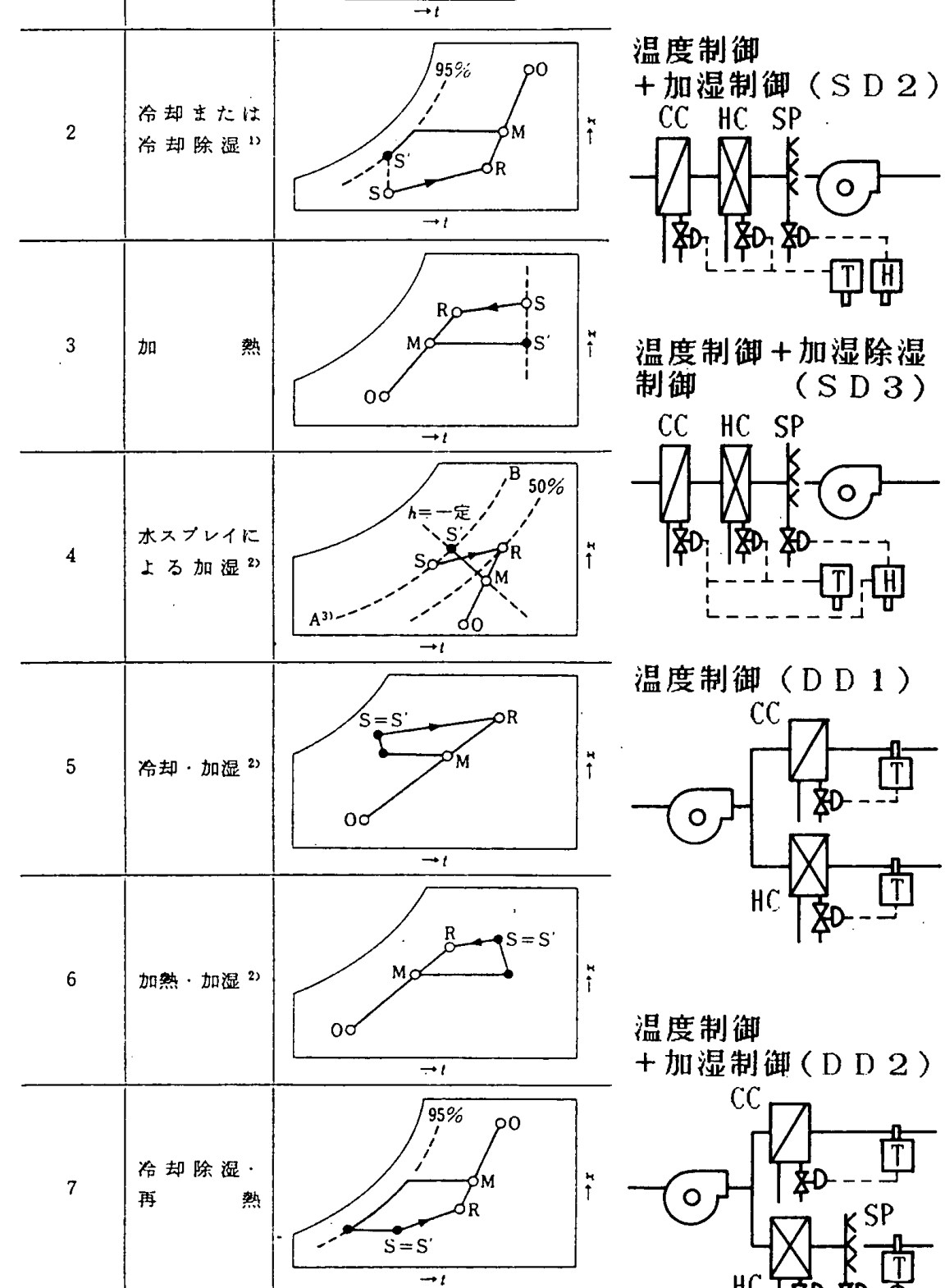

注 $\mathrm{R}$ : 室内空気， $\mathrm{O}:$ 外笑， $\mathrm{M}$ : 混合点 $\mathrm{S}$ : 要求道風空気,

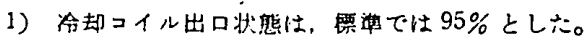

2)水スブレイのときは，加湿限界(90\%)のチェックを行 5。加湿はホスブレイのときを示したが，第笑のときる

3) 線 $\mathrm{AB}$ は $\varphi=50 \%$ の線を吹出し温度差・絶奶湿度盖 分だけ平行移㔟した曲線である。
温度制御（S D 1)

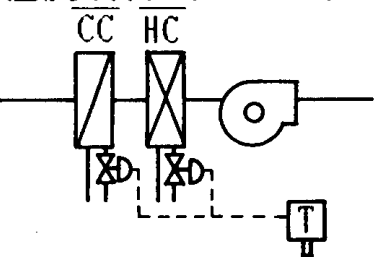

温度制御 + 加湿除湿 制御

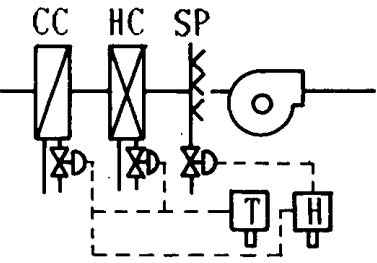

温度制御（D D 1)

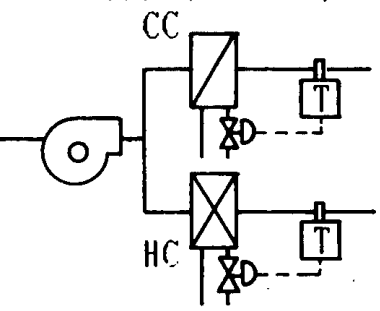

温度制御 十加湿制御 (D D 2)

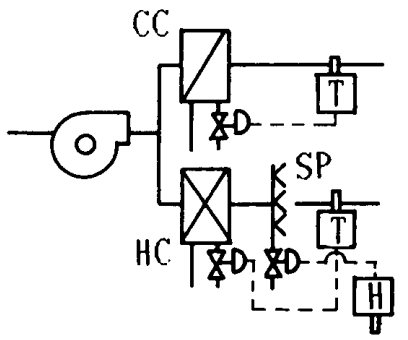

$\mathrm{CC}, \mathrm{HC}$ : 冷却,加熱コイル $\mathrm{SP}$ : 加湿器

SD 3 好除湿再熱による 湿度コントロールを行う

図一3 各種温湿度制御方式 
図上の変化に従うことになるが，例えばプロセスパター ン 2 ならば, 実際の送風空気状態は $\mathrm{S}^{\prime}$ 点であり, 理想 とする要求送風空気状態の $\mathrm{S}$ 点と相翼していることが わかり, 交換熱量としては $\mathrm{M}$ 点から $\mathrm{S}^{\prime}$ 点までの状態 変化をさせるための熱量ということになる。

\section{3 室まわりの計算}

室内での熱計算は図一 4 に示すように，室温 2 点，天 井内空気温 2 点, 壁表面温 11 点について 15 元のふく射 対流熱平衡式を立てた。床面 1 , ペリメー夕空間 14 を 例に熱平衡式を示すと，まず窓最寄りの床面 1 では,

$$
l_{1} \sum_{j=0}^{\infty} Y F_{j} \cdot t_{12, n-j}-l_{j} \sum_{j=0}^{\infty} Z F_{j} \cdot t_{1, n-j}
$$

$$
-l_{1} \alpha_{r} \sum_{i=6}^{11} F_{1, i}\left(t_{1, n}-t_{i, n}\right)-l_{1} \alpha_{c}\left(t_{1, n}-t_{14, n}\right)
$$

+ (面 1 の直達日射吸収量) + (面 1 の拡散日射 吸収量 $)+($ 面 1 の人体・照明ふく射吸収量 $)=0$

\begin{tabular}{|c|c|c|c|c|c|c|c|}
\hline \multirow{2}{*}{ 㝑狂 } & \multirow{2}{*}{ 甮湿磨 } & \multicolumn{4}{|c|}{ 熱供辁状死 } & \multirow{2}{*}{ 判別式 } & \multirow{2}{*}{ 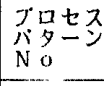 } \\
\hline & & 方式 & $c$ & HC & SP & & \\
\hline \multirow{3}{*}{$\begin{array}{l}\text { CAV } \\
\text { VAV } \\
\text { FCU }\end{array}$} & \multirow{3}{*}{ SD 1} & A & 0 & & & $t_{t_{H}} \leqq t_{t_{S}}$ & $\frac{1}{2}$ \\
\hline & & B & & 0 & & 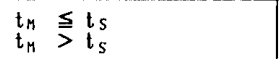 & $\begin{array}{l}3 \\
1\end{array}$ \\
\hline & & c & 0 & 0 & & $\begin{array}{l}t_{H} \\
t_{H}\end{array} t_{t_{S}}^{t_{s}}$ & $\begin{array}{l}3 \\
2 \\
2\end{array}$ \\
\hline \multirow{4}{*}{$\begin{array}{l}\text { CAV } \\
\text { VAV }\end{array}$} & \multirow{4}{*}{ S D 2} & A & & & 0 & $\begin{array}{l}x_{4} \geqq x_{1} \\
x_{4} \geqq x_{1}\end{array}$ & $\frac{4}{1}$ \\
\hline & & B & o & & 0 & 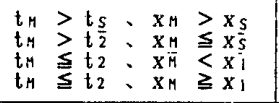 & $\begin{array}{l}2 \\
5 \\
4 \\
1 \\
1\end{array}$ \\
\hline & & C & & 0 & 0 & 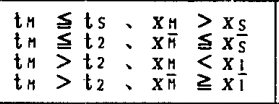 & $\begin{array}{c}3 \\
6 \\
4 \\
1 \\
1\end{array}$ \\
\hline & & D & 0 & 0 & 0 & 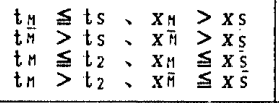 & $\begin{array}{l}3 \\
2 \\
6 \\
5\end{array}$ \\
\hline \multirow{2}{*}{$\mathrm{CAV}$} & \multirow{2}{*}{ S D 3} & A & 0 & 0 & & 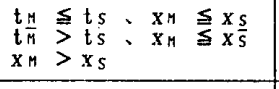 & $\begin{array}{l}3 \\
2 \\
7 \\
\end{array}$ \\
\hline & & B & 0 & 0 & 0 & 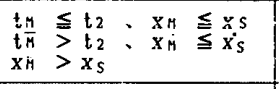 & $\begin{array}{l}5 \\
5 \\
7 \\
\end{array}$ \\
\hline \multirow{7}{*}{ D } & \multirow{3}{*}{ D D 1} & A & 0 & & & 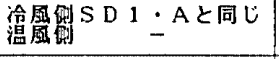 & $\begin{array}{l}\text { 冏左 } \\
\end{array}$ \\
\hline & & B & & 0 & & 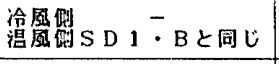 & 向左 \\
\hline & & C & 0 & 0 & & 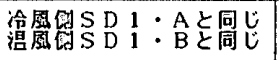 & 峝虐 \\
\hline & \multirow{4}{*}{2} & A & & & 0 & 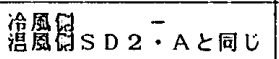 & 尚左 \\
\hline & & B & 0 & & 0 & 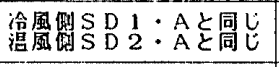 & 周左 \\
\hline & & C & & 0 & 0 & 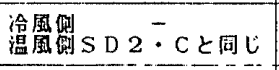 & 尚左 \\
\hline & & D & 0 & 0 & 0 & 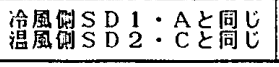 & 骨虐 \\
\hline & & & & & & \multicolumn{2}{|c|}{ 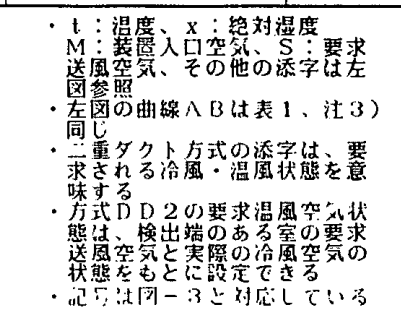 } \\
\hline
\end{tabular}

表一2 制御方法別プロセスパターンNo 識別
ペリメータ空間の 14 では,

$$
\begin{aligned}
& l_{10} \alpha_{c}\left(t_{10, n}-t_{14, n}\right)+l_{9} \alpha_{c g}\left(t_{9, n}-t_{14, n}\right) \\
& \quad+\alpha_{c} \sum_{i=6}^{7} l_{i}\left(t_{i, n}-t_{14, n}\right) \\
& \quad+a_{c} \sum_{i=1}^{3} l_{i}\left(t_{i, n}-t_{14, n}\right)+C_{p} \gamma k_{0} \cdot Q_{D p}\left(t_{0, n}-t_{14, n}\right)+q_{p} \\
& \quad+(\text { 空間 } 14 \text { に配分されるファン発熱 }) \\
& \quad+N_{0} C_{p} \gamma l_{11}\left(l_{6}+l_{7}\right)\left(t_{0, n}-t_{14, n}\right) \\
& \quad+N_{1} C_{p} \gamma l_{11}\left(l_{6}+l_{7}\right)\left(t_{15, n}-t_{14, n}\right)+(\text { 空間 } 14 \text { での人 } \\
& \text { 体・照明対流熱取得 })+\left(C_{p} \gamma+C_{F}\right) l_{11}\left(l_{6}+l_{7}\right) \\
& \quad\left(t_{14, n-1}-t_{14, n}\right) / \Delta T=0 \cdots \cdots \cdots \cdots \cdots \cdots \cdots \cdots \cdots(2)
\end{aligned}
$$

\begin{tabular}{|c|c|}
\hline 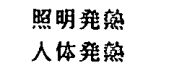 & $\begin{array}{l}\text { 上下燃流比 } 30: 70 \text { 、ふく射 } 50 \% \text { 、对流 } 50 \% \\
\text { ふく射 } 50 \% \text { 、対流 } 50 \%\end{array}$ \\
\hline ブラィンド & スラット角 $45^{\circ}$ 、スラット吸叹染 30 \%（明色） \\
\hline ブラインド & 床面にて2.5、1、0 m以上入射して、それぞれ \\
\hline 使用条件 & $\begin{array}{l}\text { の垂直面透過日射暨肪 } 100 、 200 、 300 \mathrm{kcal} / \mathrm{m}^{2} \mathrm{~h} \\
\text { 以上のとき使用 } \\
\text { 非空啁時は使用 }\end{array}$ \\
\hline すきま凮 & $\begin{array}{l}\text { 外気から、あるいはコア部からのすきま風を換気 } \\
\text { 回数で与える }\end{array}$ \\
\hline 対流熟伝遠婆 & 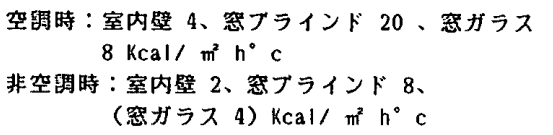 \\
\hline ふく射熟伝達宰 & $5 \mathrm{Kcal} / \mathrm{m}^{2} \mathrm{~h}^{\circ} \mathrm{c}$ \\
\hline 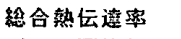 & 室外 20 、天井内・ $・ コ 78 \mathrm{Kcal} / \mathrm{m}^{2} \mathrm{~h}^{\circ} \mathrm{c}$ \\
\hline ソーン同換気 & 20 回/h（ペリメータ容崏基集）注 2) \\
\hline
\end{tabular}

\begin{tabular}{|c|c|c|c|}
\hline 稑穎 & 時問带 & フラインド状態 & 态答係数の温度励振 \\
\hline $\begin{array}{l}1 \\
2\end{array}$ & 空調時 & 使用 & $\begin{array}{l}\text { 直角三角波 } \\
\text { 二等辺三角波 }\end{array}$ \\
\hline $\begin{array}{l}3 \\
4\end{array}$ & 換気時 & 非使用 & $\begin{array}{l}\text { 直角三角波 } \\
\text { 二等辺三角波 }\end{array}$ \\
\hline $\begin{array}{l}5 \\
6\end{array}$ & 非空調時 & 使用 & $\begin{array}{l}\text { 目角三角波 } \\
\text { 二等辺三角波 }\end{array}$ \\
\hline 7 & 予熱時 & 使用 & 直角三角波 \\
\hline
\end{tabular}

となる。ここに

$Y F_{j}, Z F_{j}$ : 床の貫流, 吸熱応答係数 $\left[\mathrm{kcal} / \mathrm{m}^{2} \mathrm{~h}^{\circ} \mathrm{C}\right]$,

$F_{i, j}: i$ 面から $j$ 面をみる全形態係数， $\alpha_{r}, \alpha_{c}, \alpha_{c g}$ : 室

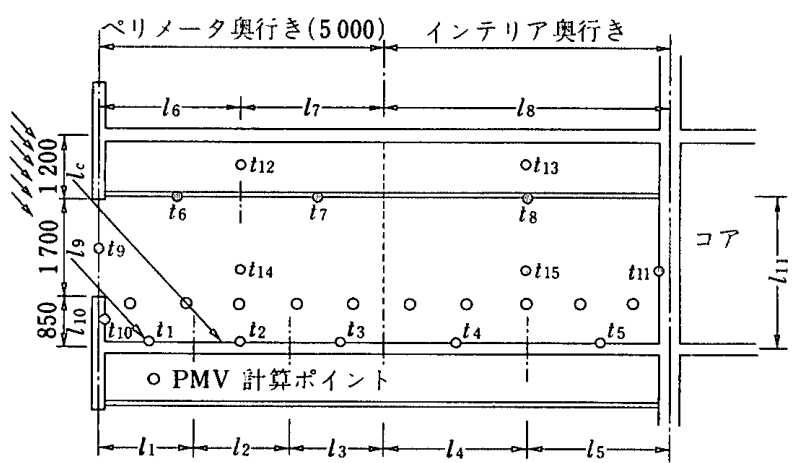

図一4 室の分割と PMV 計算ポイント

表一3 室内諸条件

表一4 顕熱平衡式係数項行列の種頪

注）予熱時：外気カット 
内各面でのふく射熱伝達率，壁面，空面での対流熱伝達 率 $\left[\mathrm{kcal} / \mathrm{m}^{2} \mathrm{~h}^{\circ} \mathrm{C}\right], t_{0}$ : 外気温 $\left[{ }^{\circ} \mathrm{C}\right], C_{\rho}, \gamma$ : 空気の比 熱, 比重 $\left[\mathrm{kcal} / \mathrm{kg}^{\circ} \mathrm{C}, \mathrm{kg} / \mathrm{m}^{3}\right], Q_{D P}:$ ペリメータへの AHU の吹出風量 $\left[\mathrm{m}^{3} / \mathrm{h}\right], k_{0}$ : 取入れ外気量比, $q_{\rho}$ : ペリメータに対するAHU, FCUの総顕熱処理量

$[\mathrm{kcal} / \mathrm{h}], N_{0}, N_{1}$ : 外気すきま風換気回数, 空間 15 から空間 14 への空気の流入換気回数 (ペリメー夕容積 基準) $[$ 回 $/ \mathrm{h}], C_{F}$ : 空気単位容積あたりの室内家具熱 容量 $\left[\mathrm{kcal} / \mathrm{m}^{3 \circ} \mathrm{C}\right], \Delta T$ : 時間增分 $[\mathrm{h}]$

(2) 式においてはペリメータとインテリアの相互換気 も考慮した。これにより,ペリメータの影響によるイン テリア冬季蓄熱負荷の增加現象や空調時室温スウィング 時の他ゾーンの影響による室温スウィング緩和効果も把 握できるようになる。( 2 ) 式左辺の 5, 6, 7 項であるが, まず 5 項の AHU での取入れ外気の影熱への影響は室内 へ侵入する外気すきま風と同様に扱うことが可能であ る。6, 7 項めは, 吹出口の状態をパラメータとしない で䫓熱平衡を考えるとこのようになる。 $q_{s p}$ にダクトの ヒートロスをいれることも可能であり，機械換気のみの ときもこの式で表され $q_{s p}=0$ となる。また後で述べる 室温重み係数の利用のためには AHU, FCU の顕熱処 理量をパラメータとする方法が便利になってくる。その 他の諸条件は表一 3 に示す。

顕熱平衡の行列式は, 空調時と非空調時で対流熱伝達 率が異なることやブラインドの使用状態, 応答係数の温 度励振の波形の違いなどにより数種類になる。表一4は， この係数項行列の種類を示したものである。

潜熱平衡については, 壁体などの吸放湿の遅れは無視 し、またインテリア，ペリメータの区別をせず 1 室計算 とした。

\section{4 人体温熱環境の計算}

PMV 計算ポイントは, 図一4に示したように奥行き 方向にペリメータ 5 点, インテリア 5 点とし, 高さは床 上 $600 \mathrm{~mm}$ とした。また気流速度は $0.2 \mathrm{~m} / \mathrm{s}$ で一定とし た。

MRT の計算には，照明からのふく射，拡散日射の室 内への透過成分, 直達日射についてはブラインドでの多 重反射後の透過成分も含めて計算した。また室内家具

（机，いす，本箱）などの影響も考虑することとし，家 具を室温と等しいとして, 人対面の形態係数を補正した。 ポイントjにおける MRT を式で表すと,

$$
\begin{aligned}
M R T_{j}= & \sum_{i=1}^{11}\left\{t_{i} \cdot f_{i}+t_{r} \cdot\left(1-f_{i}\right)\left\{F_{j, i}\right.\right. \\
& +t_{s} \cdot f_{9} \cdot F_{j, 9}+\sum_{i=6}^{8} t_{L, i} \cdot f_{i} \cdot F_{j, i}
\end{aligned}
$$

ここに, $t_{i}: i$ 壁面の表面温度 $\left[{ }^{\circ} \mathrm{C}\right], t_{r}$ : 室温 $\left[{ }^{\circ} \mathrm{C}\right]$, $f_{i}$ : 人体から $i$ 面をみるときの家具の影響による補正 係数, $F_{j, i}: j$ 点の人体から $i$ 面をみる形態係数, $t_{s}$
: 拡散日射およびブラインド使用時直達日射の透過成 分の等洒温度 $\left[{ }^{\circ} \mathrm{C}\right], t_{L, i}: i$ 天井面照明発熱のふく射

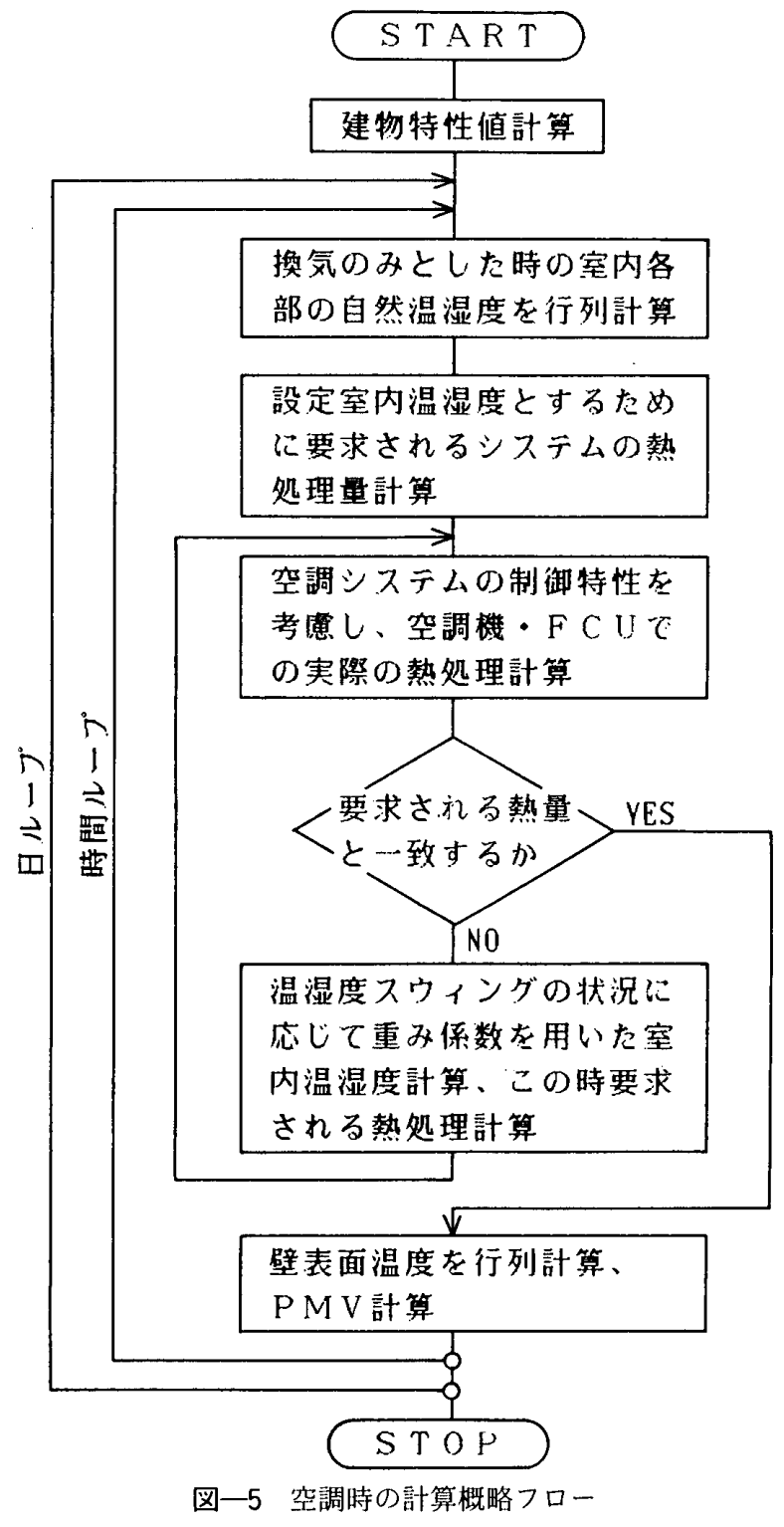

表一5 室温バターンとその例

冷房期冷熱源, 暖房期温熱源のみ運転可能なシステムの

\begin{tabular}{|c|c|c|c|}
\hline & 室温バターン & $\begin{array}{l}\text { A H U、F C. U T } \\
\text { の処理状態 }\end{array}$ & 例 \\
\hline (a) & $\begin{array}{l}\text { ベリメータ・ } \\
\text { インテリアとも } \\
\text { 設定窒温 }\end{array}$ & $\begin{array}{l}\mathrm{AHU} \cdot \mathrm{FCU} \\
\text { む影熱処理 }\end{array}$ & $\begin{array}{l}\text { 冷而期にバリメータ、インテ } \\
\text { リアとも冷房を要求している }\end{array}$ \\
\hline (b) & $\begin{array}{l}\text { インテリアのみ } \\
\text { 設定室温 }\end{array}$ & $\begin{array}{l}\text { A H Uのみ } \\
\text { 瀕熱処理 }\end{array}$ & $\begin{array}{l}\text { 暖房期で日射の強い日に、1 } \\
\text { ンテリアで暖房、ベリメータ } \\
\text { で泠房を要求している }\end{array}$ \\
\hline (c) & $\begin{array}{l}\text { ヘリリータのみ } \\
\text { 設定室温 }\end{array}$ & $\begin{array}{l}\text { FCU影熱処理、 } \\
\text { A HUは処理なし } \\
\text { か加湿のみ }\end{array}$ & $\begin{array}{l}\text { 中間期に近い冷房期に、イン } \\
\text { テリアで玲房、ベリメータで } \\
\text { 暖房を要求している }\end{array}$ \\
\hline (d) & $\begin{array}{l}\text { ベリメータ・ } \\
\text { インテリアとむ } \\
\text { 室温スウィング }\end{array}$ & $\begin{array}{l}F C U \text { 処理なし } \\
A H U は \text { 処理なし } \\
\text { か加湿のみ }\end{array}$ & $\begin{array}{l}\text { 中間期に近い暖房期に、ペリ } \\
\text { メータ、インテリアとむ伶房 } \\
\text { を要求している }\end{array}$ \\
\hline
\end{tabular}
場合の例

注）コイル能力限界による室温スウィングは考えていいない 
成分の等価温度 $\left[{ }^{\circ} \mathrm{C}\right]$

となるれ

$\mathrm{M}$ 值 (代射量) の年変動は $60 \sim 50 \mathrm{kcal} / \mathrm{m}^{2} \mathrm{~h}$, clo 值 (基 本着衣量）は $1.0 \sim 0.6$ clo とし，ともに旬平均外気温 によってスケジュールさせた。旬平均外気温の最低期が $\mathrm{M}=60, \mathrm{clo}=1.0$ であり，最高期が $\mathrm{M}=50, \mathrm{clo}=0.6$ である。

\section{3. 重み係致を用いる空調時計算法}

\section{1 空調時の計算概略フロー}

空調時の室内温湿度, 壁表面温度, システムでの熱処 理量計算の概略フローを図一 5 に示す。図一 5 の中の実 際の熱処理計算というブロックは，表一1, 表一 2 で示 した機能の判別および空気状態変化の計算を行う。まず 機械換気だけとしたときの自然室内温湿度, 自然壁表面 温度を 15 元の行列計算より求める。これをもとに室内 設定温湿度とするためにシステムで処理すべき熱量を計 算する。これとシステムの制御特性で決まる実際の処理. 熱量が一致しない場合は温度あるいは湿度のスウィング が生じる。そのときは，新たに室内温湿度，システムで 処理すべき熱量を計算し直すが，室温計算は行列計算に はよらず,熱処理量に対する室温重み係数を用いて行う。 そして室側の要求する熱量とシステムで処理した熱量が 一致するまで計算を反復する。壁表面温度は, 熱量が得 られた後空調による温度変化分を計算して，これと自然 温度との和として求まる。

\section{2 重み係数を用いる室温計算法}

空調時の室温は空調システムの制御可能な範囲を超え ると温度スウィングを起こす。表一5は，ペリメータ， インテリアの室温の状態をパターンに分け，その例を示

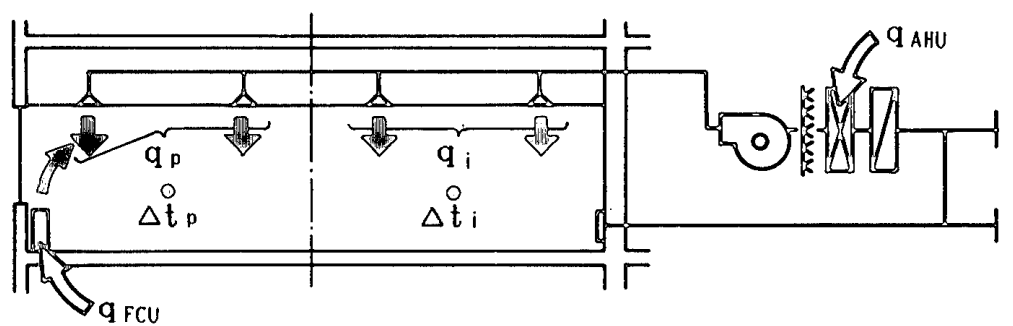

図一6 空調システムの顥熱処理量と室温変化
したものである。室温計算は，この室温パターンに応じ て行うことになる。行列計算で行うときは, 表一 5 の (a) の場合は 13 元，(b) あるいは (c) の場合はそれぞれ 14 元，(d) の場合は 15 元の行列計算を使い分けること になり，係数項行列の種類も多くなる。また顕熱処理量 の反復計算中は壁表面温度が不要であるので，この部分 に対して行列計算のかわりに重み係数による室温計算法 を導入すると計算の複雑化が避けられる。こうすると行 列計算は, 自然温度計算時と, 顕熱処理量が得られた後 の空調による温度変化分計算のみ 15 元のものを使えば よい。さらに重み係数を用いることの上記事項に優るメ リットは，予熱計算への適用が容易であるという点であ る。

次に重み係数による室温計算式について述べる。重み 係数は，各ゾーンに対する空調システムの顕熱処理量に 対する室温重み係数を用いる。図一6 は空調システムの 顕熱処理量とこれによる室温変化分の説明図である。ペ リメータ，インテリアに対する空調システムの顕熱処理 量 $q_{\rho}, q_{t}$ は次式で表される。

$$
\begin{aligned}
& q_{P}=q_{F C U}+\frac{Q_{D P}}{Q_{D P}+Q_{D i}} \cdot q_{A H U} \\
& q_{t}=\frac{Q_{D t}}{Q_{D P}+Q_{D i}} \cdot q_{A H U} \cdots \cdots \ldots . .
\end{aligned}
$$
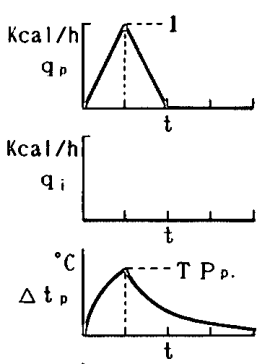

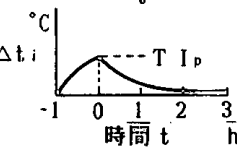

(a) $q_{p}$ 励振時
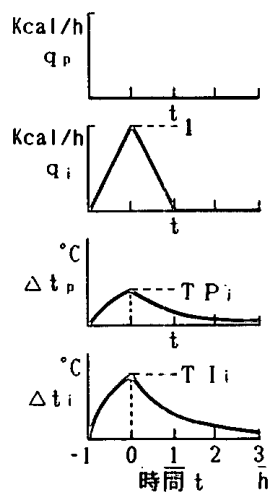

（b） $\mathrm{q}_{\mathrm{i}}$ 励振時
图一7 顕熱処理量の二等辺三角波励振に 対する室温重み保数

\begin{tabular}{|c|c|c|c|c|c|}
\hline 室温バターン & $\Delta \mathrm{t}_{\mathrm{p}}$ & $\Delta \mathrm{t}_{\mathrm{i}}$ & $q_{p}$ & $\mathrm{q}_{i}$ & $\Delta \mathrm{t}_{\mathrm{p}}, \Delta \mathrm{t}_{\mathrm{i}}$ ：空铜に上 \\
\hline $\begin{array}{l}\text { (a) ベリメータ・インテリ } \\
\text { フとも設定室温 }\end{array}$ & 瞅知 & 睡知 & $\begin{array}{l}\Delta \mathrm{t}_{i} \cdot T P_{i}-\Delta t_{p} \cdot T I_{i} \\
T I_{p} \cdot T P_{i}-T P_{p} \cdot T I_{i}\end{array}$ & $\frac{\Delta t_{p} \cdot T I_{p}-\Delta t_{i} \cdot T P_{p}}{T I_{p} \cdot T P_{i}-T P_{p} \cdot T I_{i}}$ & 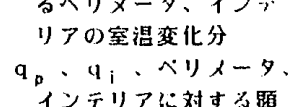 \\
\hline $\begin{array}{l}\text { (b) インテリアひみ } \\
\text { 設定室温 } \\
\end{array}$ & (ii) 式 & 挠知 & $k_{Q} \quad q_{i}$ & $\frac{\Delta t_{i}}{\therefore_{Q} T l_{p}+T l_{i}}$ & $\begin{array}{l}\text { 熱处理黑 } \\
k_{Q}=Q_{D P} / Q_{D 1}\end{array}$ \\
\hline $\begin{array}{l}(\because) \text { ヘリメータのみ } \\
\text { 钤定室温 }\end{array}$ & 既知 & (7) 式 & $\frac{\Delta t_{p}-q_{i} T P_{i}}{T P_{p}}$ & 既知莡） & $\begin{array}{l}\text { 場合は0、加湿のみ行 } \\
\text { なう場合は加湿に伴う } \\
\text { 顕熱处理㩖が相当する }\end{array}$ \\
\hline $\begin{array}{l}\text { (d) バリメータ・インテリ } \\
\text { アとも室温スウィンク }\end{array}$ & (6) 式 & (7) 式 & $k_{Q} \quad a_{i}$ & 樶知 ${ }^{*}$ ) & \\
\hline
\end{tabular}

表一6 室温パターンと室温および顕熱処理量計算式 
ここに， $q_{A H U}, q_{F C U}: \mathrm{AHU}, \mathrm{FCU}$ での顕熱処理量陆社) $[\mathrm{kcal} / \mathrm{h}], Q_{D P}, Q_{D i}:$ ペリメー夕, インテリアへのAHU 送風量 $\left[\mathrm{m}^{3} / \mathrm{h}\right]$

$q_{\rho}, q_{i}$ の単位二等辺三角波励振の室温応答は模式的に 図一7のように示される。通常の時間带においては,こ の応答の時間 0 の值のみを室温重み係数として用いる。 空調による室温変化はいまの室温重み係数を用いて次式 で表される。

$$
\begin{aligned}
& \Delta t_{p}=q_{p} \cdot T P_{\rho}+q_{i} \cdot T P_{i} \\
& \Delta t_{i}=q_{p} \cdot T I_{p}+q_{i} \cdot T I_{i} \cdot
\end{aligned}
$$

ここに， $\Delta t_{p}, \Delta t_{i}$ : 空調によるペリメータ，インテ リアの室温変化 $\left[{ }^{\circ} \mathrm{C}\right]$,

$T P_{p}, T I_{\rho}$ :ペリメー夕に対する顕熱処理量に対する 室温重み係数 $\left[{ }^{\circ} \mathrm{Ch} / \mathrm{kcal}\right]$

$T P_{i}, T I_{i}$ ：インテリアに対する顕熱処理量に対する

$\mathrm{R}$ : 室内空気 $\mathrm{O}$ : 外気 $\mathrm{M}$ : 混合空気 $\mathrm{S}$ : 送風空気 qAHU.8：予熱予冷開始時AHU 影熱処理量 qAHU,9：予熱予佮終了時AHU 顕熱処理量
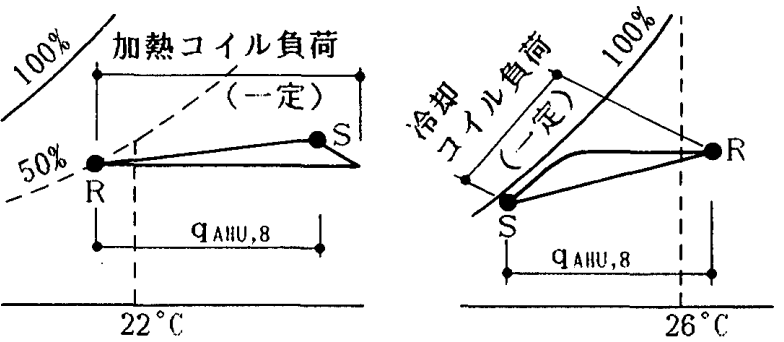

予熱開始時（外気カット）予冷開始時（外気力ット）

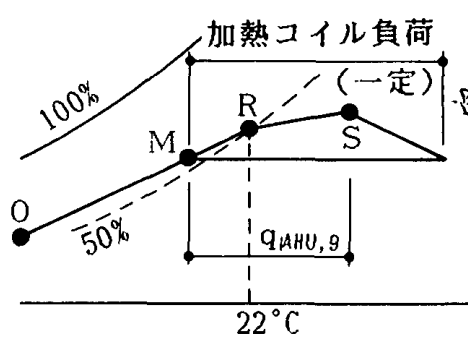

予熱終了時

(a) 暖房期

加熱コイル＋水スフレ による制御

図一8 予熱予冷時コイル負荷一定とした時の空気線図上の各状 態値と熱量
室温重み係数 $\left[{ }^{\circ} \mathrm{Ch} / \mathrm{kcal}\right]$

(6)，（7）式より，室温パターンに応じた室温および 要求する顕熱処理量の計算式は表一6のようにまとめら れる。

表一6の (a), (b) の場合と（c)，(d) で $q_{i}=0$ (AHUで処理なし) の場合とは, $\Delta t_{\rho}, \Delta t_{i}, q_{\rho}, q_{i}$ は 即座に求まる。すなわち, 図一5における 1 回目の室ま わり，システムまわりの計算でじの室温パターンに属す るかが判明して，2回目の計算で $\Delta t_{p}, \Delta t_{i}, q_{p}, q_{i}$ の 正解が得られるわけである。しかし, (c), (d) で $q_{i} \neq 0$ (AHUで加湿のみ) の場合は, 加湿に伴う顕熱処理で 室温は成行きまかせで相対湿度のみ設定值という状態を 求めることになり，これは収束計算に頼ることになる。

\section{4. コイル最大負荷計算への展開}

\section{1 予熱予冷時の考え方}

最大負荷計算を行うにあたり，最も問題となるのは予 熱予冷時の扱い方である。従来は予熱予冷時室除去熱量 一定とした計算が発表されている5 。しかしピーク時の 装置制御特性や装置設計上の問題を検討可能とするため には，より現実的に装置側負荷一定とする方がよい。本 論では，装置としては室内環境に直接関係する $\mathrm{AHU}$, FCUを対象としているので，これらのコイル負荷が予 熱予冷時一定で予熱予冷終了時に設定室温となる計算法 を考えた。

予熱予冷時（以降は予熱時と省略する）コイル負荷一

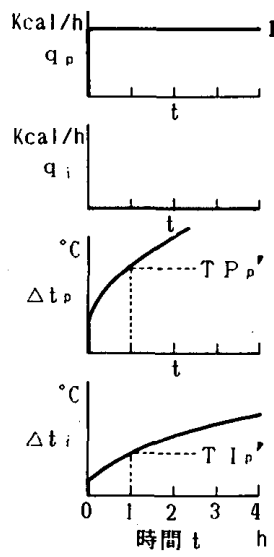

(a) $q_{p}$ 励振時

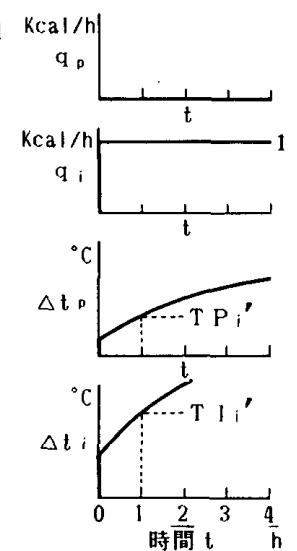

(b) $q_{i}$ 励振時
図一9顕熱処理量の単位ステップ変化に対する室温重み係数

\begin{tabular}{|c|c|c|c|c|}
\hline 室温バターン & $\Delta t_{p}$ & $\Delta \mathrm{t}_{\mathrm{i}}$ & $q_{p}$ & $q_{i}$ \\
\hline $\begin{array}{l}\text { (a) ベリメータ・イン } \\
\text { テリアとも設定室温 }\end{array}$ & 眠知 & 晖知 & $\begin{array}{l}\left(\Delta t_{p}-q_{i} T P_{i}^{\prime}+\Delta q_{p} T P_{p}\right. \\
\left.+\Delta q_{i} T P_{i}\right) / T P_{p}^{\prime}\end{array}$ & 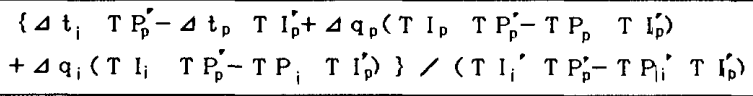 \\
\hline $\begin{array}{l}\text { (b) インテリアのみ } \\
\text { 設定室温 }\end{array}$ & (8) 式 & 㽣知 & $\mathrm{k}_{Q} \mathrm{q}_{\mathrm{i}} \quad \mathrm{k}_{\mathrm{Q}}=\mathrm{Q}_{\mathrm{DP}} / \mathrm{Q}_{\mathrm{D}_{1}}$ & $\left\{\Delta \mathrm{t}_{i}+\Delta \mathrm{q}_{\mathrm{i}}\left(\mathrm{k}_{\mathrm{Q}} \mathrm{T} \mathrm{I}_{\mathrm{p}}+\mathrm{T} \mathrm{I}_{\mathrm{i}}\right)\right\} /\left(\mathrm{k}_{\mathrm{Q}} \mathrm{T} \dot{I}_{p}+\mathrm{T} \mathrm{L}_{\mathrm{i}}\right)$ \\
\hline $\begin{array}{l}\text { (c) ペリメータのみ } \\
\text { 钤定室温 }\end{array}$ & 眠知 & (9) 式 & $\left(\Delta t_{p}+\Delta q_{p} T P_{p}\right) / T P_{p}^{\prime}$ & 0 \\
\hline
\end{tabular}

表一7 予熱終了時の室温および開始時顕熱処理量の計算式（予熱 1 時間）

脚注）この処理熱量にはファン発熱は含んでいない。ファン発熱は別途考慮している。 
定の場合，室除去熱量はまず一定にならない。また $\mathrm{AHU}, \mathrm{FCU}$ での顥熱処理量 $q_{\text {AHU }}, q_{F C U}$ も一定になると は限らない。図一8は予熱時コイル負荷一定としたとき の予熱開始, 終了時の空気線図上の状態点を示したもの である。暖房期, 冷房期について AHU の代表的制御方
式を例にしている。予熱時コイル負荷一定の場合, 室除 去熱量は外気負荷や室潜熱負荷の変動の影響を受け，ま た $q_{\text {AHU }}$ はスプレや泠却コイルでの潜熱処理の状態変動 の影響を受けて，予熱中増減する ${ }^{[14)}$ 。図一8のように予 熱開始時に外気カットとするときにはその増減量は大き
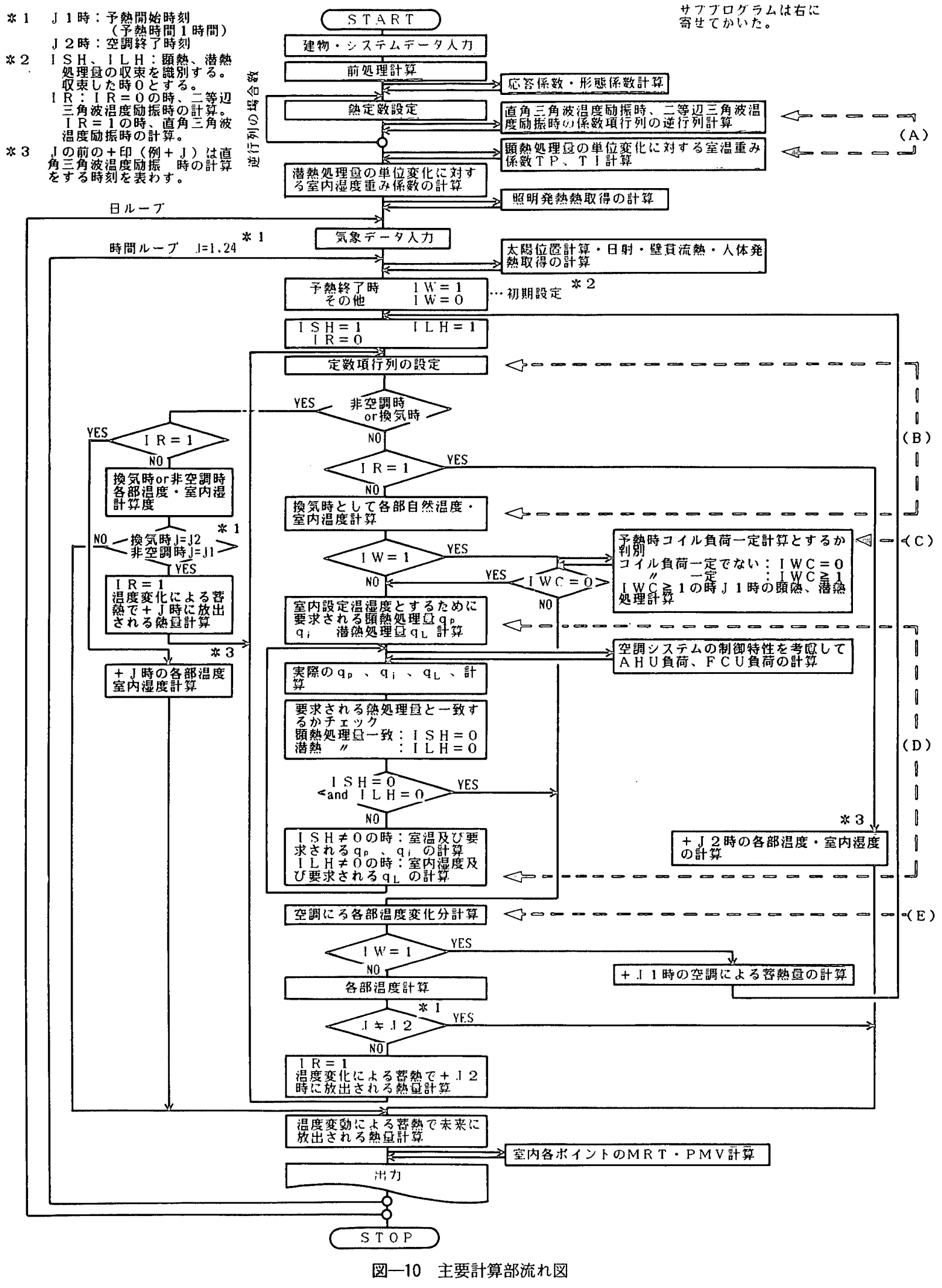
曰ルーブ 
くなる。

コイル最大負荷を求めようとする場合には，装置容量 は無限にあるものとし, 常に予熱時はコイル負荷一定と する計算を行う。

\section{2 予熱時コイル負荷一定の計算方法}

予熱時の室温計算には，顕熱処理量の二等辺三角波励 振の亡きの室温重み係数 $T P_{p}, T I_{\rho}, T P_{i}, T I_{i}$ の他に ステップ変化のときの室温重み係数も用いる。これを図 一9に示す。ここでは予熱 1 時間のときのみを考える。 予熱開始時の各ゾーンに対する顕熱処理量を $q_{p}, q_{i}$, 終了時を $q_{p}-\Delta q_{p}, q_{i}-\Delta q_{i}$ とすると，終了時の空調に よる室温変化は,

$$
\Delta t_{p}=q_{p} \cdot T P_{p}^{\prime}+q_{i} T P_{i}^{\prime}-\Delta q_{p} T P_{p}-\Delta q_{i} T P_{i}
$$

$$
\Delta t_{i}=q_{\rho} T I_{\rho}^{\prime}+q_{i} T I_{i}^{\prime}-\Delta q_{\rho} T I_{\rho}-\Delta q_{i} T I_{i} \cdots \cdots(9)
$$

ここに, $\Delta t_{p}, \Delta t_{i}$ : 予熱終了時のペリメー夕，イン テリアの予熱による室温変化 $\left[{ }^{\circ} \mathrm{C}\right], T P_{\rho}^{\prime}, T I_{\rho}^{\prime}$ : ペリ メータに対する顕熱処理量の単位ステップ変化の場合の ペリメータ，インテリアの室温重み係数 $\left[{ }^{\circ} \mathrm{Ch} / \mathrm{kcal}\right]$, $T P_{i}^{\prime}, T I_{i}^{\prime}$ : インテリアに対する影熱処理量の単位ス テップ変化の場合のペリメータ, インテリアの室温重み 係数 $\left[{ }^{\circ} \mathrm{Ch} / \mathrm{kcal}\right]$ となる畔社。ままた $\Delta q_{\rho}, \Delta q_{i}$ は，

$$
\begin{aligned}
& \Delta q_{\rho}=\Delta q_{F C U}+\frac{Q_{D P}}{Q_{D P}+Q_{D i}} \cdot \Delta q_{A H U} \\
& \Delta q_{i}=\frac{Q_{D i}}{Q_{D P}+Q_{D i}} \cdot \Delta q_{A H U} \ldots \ldots \ldots \ldots
\end{aligned}
$$

ここに, $\Delta q_{\text {AHU }}, \Delta q_{F C U}: \mathrm{AHU}, \mathrm{FCU}$ での予熱開始時, 終了時の顕熱処理量差 $[\mathrm{kcal} / \mathrm{h}]$

となる。 $\Delta q_{A H U}, \Delta q_{F C U}$ をある值に仮定すると，予熱終 了時の室温パターンに応じて, $\Delta t_{p}, \Delta t_{i}, q_{p}, q_{i}$ の計 算式は表一7のように表される。これらの式を用いて， 予熱時に AHUとFCUのコイル負荷が一定となるよう な $\Delta q_{A H U}, \Delta q_{F C U}$ を収束計算により求めればよい。

\section{5. 具体的計算手順}

図一10に主要部計算流れ図を示す。日，時刻ループ の手前の (A) の部分で, 各部温度計算に用いる逆行列 や室温重み係数を計算する。(B) は自然温湿度を計算 する部分，(D) は室まわりとシステムまわりの計算を 反復して室温, 顥熱処理量を求める部分，(E) は (D) で得られた顕熱処理量をもとに空調による各部温度変化 分を計算する部分である。予熱中は自然温湿度の計算を 行い, 予熱終了時刻に予熱時コイル負荷の計算を行う。 これが (C) 部分である。また空調開始, 終了時の各部 温度計算は，その前後で対流熱伝達率が異なるので，2 種類の直角三角波壁表面温度励振の熱流応答を重ね合せ

脚注) 予熱 2 時間以上の場合は，図一7の室温重み係数は時 間 0 以外のものも用いることになる。
る手法をとった。表一1, 表一2の機能の判別および空 気状態変化の計算は，図一10の (D) 内にあるサブプ ログラムで行われる。

\section{結 論}

1) $\mathrm{AHU}, \mathrm{FCU}$ の温湿度制御特性と建物の熱特性を できるだけ詳しく考慮して PMVとコイル負荷を計算す る手法を示した。これにより，従来よく使われてきた室 温と除去熱量などの指標よりもより現実を反映した指標 で, 室内環境亡エネルギ消費量を総合的把握・考察する ことが可能となった。

2) 相互に影響をおよぼし合うインテリア，ペリメー タ2ゾーンの室温計算が可能になった。，室温重み係数を 用いることにより, 空調時室温スウィング時の計算が簡 明になり，また予熱計算が可能になった。

3）コイル負荷一定となる予熱計算法を示した。これ によりより現実的なコイル最大負荷が得られるように なった。

4）本計算手法を適用することにより, 従来の手法で は不可能であったものとして, 温熱環境とエネルギー消 費量の同時評価の試算，特に暖房最大負荷計算における 熱負荷の試算，事務所建築におけるペリメータ，、インテ リア両ゾーンの環境特性の試算などがかなりの精度で行 える見通しがたった。

\section{参考文献}

1) 石野久爾, 郡 公子：空調方式とエネルギー・室内温熱 環境評価に関する理論構成, 日本建築学会建築環境工学 論文集, 1983 年 11 月, p. 103 108

2）郡 公子, 石野久弹: 室内環境亡空調エネルギ解析のた めの精算プログラムに関する研究一最大負荷計算への展 開一, 空気調和・衛生工学会学術論文集, 1984 年 10 月, p. $605 \sim 608$

3）石野久㪷：体感温度の年間シミュレーション, 空気調和・ 衛生工学 Vol. 59, No. 4, 1985 年 4月, p. 331 341

4) 福島正之, 岩崎博志, 中原信生：非空調時に於ける空温 変動の予測と実測, 日本建築学会大会学術講演梗概集, 1978 年 9 月, p. $355 \sim 356$

5) 武田 仁: 非空調室の室温変動解析, 空気調和 - 衛生工 学会論文集 No.7, 1978 年 6 月, p. 13 21

6) 石野久雨：天井排熱システムの設計用熱負荷計算, 空気 調和・衛生工学 Vol. 46, No. 10，1972 年 10 月, p. 9 22 注

1) 第 2 章で用いる主要な用語の定義を示す。 要求送風空気：室まわりの計算で得られた負荷を処理す るために要求される送風空気状態

実現送風空気：空調機まわりの計算で得られた実際の送 風空気状態

設定室内温湿度とするために要求される処理熱量：言葉 ビおり

要求される熱量：室まわりの計算で得られた負荷 実際の処理熱量：空調機まわりの計算で得られた実際の システムでの交換熱量

以上各用語は，室よシステムの収束計算のあることや， 
システムの制御限界があるために使いわけたものである。

2) 文献 4) の実測值より, 厳寒期のインテリアとペリメー 夕の非空調時明け方の温度差が約 $1^{\circ} \mathrm{C}$ と判断し, 同条件 でのシミュレーションによって換気回数を逆算した。そ の結果室温差に対する換気回数の感度は, 回数の増加と ともに対数的に鈍くなるが，20回前後と仮定できた。空 謂時については実測值がないので同一値と仮定した。

3）家具の影響によって, 人体から全壁面, 全床面が見える わけではないということを式で示した。本来なら壁対床 などの面対面のふく射の式においても家具の影響を考慮
すべきであるが, 室内側 $\alpha_{c}, \alpha_{r}$ の值の精度の問題と同時 に解決すべきであると考え，これについては家具の影響 を含んだ式としていない。 $f_{i}$ は室形態によらず天井面に 対しては1.0, その他の面に対しては 0.5 とした。 $F_{j . i}$ は P. O. Fanger や中村の手法を参考にして求めた。

4）図一8において，暖房期には加熱コイルは加湿に伴う冷 却分を補う必要がある。このため予熱中の $q_{\text {AHU }}$ は加湿量 の変動の影響を受けて増诚する。冷房期には冷却コイル は全熱を処理する。予熱中の成行きの潜熱交換量変動分 だけ $q_{\text {AHU }}$ も変動する。

\section{SYNOPSIS}

UDC : 697. $11: 697.003 .1$

\section{A STUDY ON TOTAL EVALUATION METHOD OF THERMAL ENVIRONMENT AND $\mathbb{E N E R G Y ~ C O N S U M P T I O N ~}$}

by $\mathbb{K I M} \mathbb{M} O \mathbb{K O H R \mathbb { R }}$, Research Associate of Utsunomiya Unjversity and Dr. HISAYA ISHINO, Associate Professor of Tokyo Metropolitan university, Members of A. I. J.

The mission of air-conditioning system is primarily to maintain space thermal comfort for occupants. It is important to design proper systems which achieve this mission and, at the same time, conserve energy. Both of thermal comfort and energy consumption depend on control performance of systems and characteristics of space thermal response. It is required that accurate simulation method and total evaluation method on space themal comfort and energy consumption. This paper deals with such simulation method appliable to office buildings. Fanger's PMV is used as thermal comfort index and cooling or heating coil load in AHU or FCU is used as energy index. Coil loads in AHU or FCU are simulated under the assumption, not that space extraction rate is constant, but that coil load is cons-tant, during warming up or pulling down. 